\title{
HOTS Implementation in French Learning Assessment in High Schools
}

\author{
Nani Kusrini ${ }^{1}$, Feni Munifatullah ${ }^{2}$, Indah Nevira Trisna ${ }^{3}$ \\ \{ nani.kusrini@ fkip.unila.ac.id ${ }^{1}$, feni.munifatullahl@fkip.unilaa.ac.id ${ }^{2}$, Indah.nevira@ fkip.unila.ac.id ${ }^{3}$ \}
}

French Education Department, University Of Lampung, Indonesia ${ }^{1,3}$, English Education Department, University Of Lampung, Indonesia ${ }^{2}$

\begin{abstract}
The 2013 curriculum aims to create generation that has 21 st century skills: creative, critical thinking, communicative and collaborative (4C). To achieve this goal, it is necessary to integrate higher thinking skills (HOTS) in learning. This study aims to identify the implementation of HOTS in learning assessement of French in high school and to describe the understanding level of French teachers about HOTS and its implementation. It is a qualitative descriptive analytic study with documentation and in-depth interviews for data collection. In this research, 8 packages of grade 10 final tests from five schools in Lampung, totaling 348 questions and interviews are used as sources of data. The results of the analysis show that the composition of the questions on the exam already contains questions with HOTS characteristics consecutively as follows : remembering/C1 $(36.78 \%)$, understanding/C2 (53.16\%), applying/C3 (7.47\%), analyzing/C4 (2.58\%). Evaluation is an important aspect but cannot be separated from the objectives and the learning process. Referring to the interview with five French teachers, the low percentage of HOTS questions is due to the lack of their knowledge in designing HOTS questions and implementing HOTS-based learning process. On the other hand, the description of basic competencies in French syllabus that they use as reference in determining objectifs and learning process does not relfect the higher thinking order.
\end{abstract}

Keywords: Higher Order Thinking Skill (HOTS), assessment, French syllabus.

\section{Introduction}

The rapid development of science and technology, especially in the field of communication, brings not only changes but also new demands. The complex life problems force humans to adapt quickly in order to survive in this increasingly competitive life. The ability of literacy, critical and creative thinking is predicted to be the skills needed to face life's problems in this century.

The government is well aware of this situation. As an effort to prepare the generation with these abilities, the 2013 curriculum was then implemented as a complement to the previous curriculum. The curriculum, which emphasizes in strengthening character education and scientific approaches, aims to build the character of students and equip the golden generation of Indonesia with 21 st century skills, including critical thinking and problem solving skills.

High-order thinking skills and problem solving commonly called HOTS has become educational goals not only in Indonesia. The Education system worldwide has also developed framework on increasing emphasis on thinking skills as one of the skills of the 21st century [1]. In fact, over the decades, the aim of developing and enhancing students' higher order thinking (HOT) has been a major educational goal [2]. 
It was originally a concept about the categorization of educational goals introduced by Benjamin S. Bloom. Initially, there were only two domains in this taxonomy, namely the cognitive domain and the affective domain. Finally, his colleague Simpson added one domain to complete, namely the psychomotor domain [3].

Bloom's Taxonomy of thinking level is widely used. This taxonomy was later revised by Anderson \& Krathwohl . For the cognitive domain, Bloom classified thinking skills into six levels, namely 1) remembering, 2) understanding, 3) applying, 4) analyzing, 5) evaluating and 6) creating (creating). The six levels are then divided into two groups, namely Lower Order Thinking Skill (LOTS) and Higher Order Thinking Skill (HOTS).

The main purpose of high order thinking skills is related to the ability to think critically in receiving various information, think creatively to solve problems using the knowledge they have. According to Krulik and Rudnick, problem solving is a process. The pattern of problem solving is explained into steps that can be addressed to students, namely 1) reading a problem, 2) developing information, 3) choosing a strategy, 4) solving the problem, and 5) checking and expanding. table:

The concept of high order thinking skills is based on several opinions as in the following

Table 1. Basic concepts of HOTS

\begin{tabular}{ccc}
\hline $\begin{array}{c}\text { Problem solving Krulik \& } \\
\text { Rudnick (1998) }\end{array}$ & $\begin{array}{c}\text { Cognitive Level of Bloom } \\
\text { Taxonomy (1959) }\end{array}$ & $\begin{array}{c}\text { Revised Bloom Taxonomy } \\
\text { (Anderson and } \\
\text { Krathwohl, 2001) }\end{array}$ \\
\hline Recall & Knowledge & Remember \\
Basic & Comprehension & Understand \\
& Application & Apply \\
Critical & Analysis & Analyze \\
Creative & Synthesis & Evaluate \\
& Evaluation & Create \\
\hline
\end{tabular}

Assesment is an important stage that needs to be carried out in every process/effort and is used as a tool to determine if the objectives are already achieved or not. On the other hand, learning is a series of processes that are gradually and systematically arranged by educators who use it to interact with students so as to make changes to their students both in terms of knowledge, abilities and skills. So to find out if the learning objectives have been achieved or not, it is necessary to carry out an evaluation.

Assesment in education practices cannot be seen from just one aspect, for example the final exam or national exam alone. Many things are involved in it. It is a a triangulation - or a close relationship between three components - namely between a) learning objectives, b) learning activities or teaching and learning activities, and evaluation.

According to preliminary study and observation, it is found that many items in French examination have not explored higher thinking skills of student in one or another by concentrating only certain language component. Moreover, assessment/evaluation can not be separated from other learning activities. Therefore, this study aims to explore deeper the HOTS implementation in educational practices which involves learning process and assesment in French classrooms. 


\section{Method}

This research adopts descriptive qualitative analytical method because it aims to identify the HOTS implementation in French learning process and evaluation in high schools and also to describe the understanding level of teachers toward HOTS and its application in the classroom. The data were collected by documentation, analysis and in-depth interviews.

French is a foreign language other than English that is taught at the high school in Indonesia. In Province of Lampung, there are only 7 schools that gives French as specialization subject. According to the policy of some schools, it is not offered at all levels. This subject is generally given in class $\mathrm{X}$ or first level of high school.

HOTS learning does not require students with certain abilities or level, but can be applied at all levels of education. Beside that, the availability of sufficient data sources and the willingness of the teacher to provide the documents of the final exam questions already tested became the main reasons why the researchers used the final exam documents for odd and even semester of class $\mathrm{X}$ from five schools as primary data source.

This data source consists of 8 packages of final exams (odd and even semesters) containing a total of 348 items in which there are quantitative data consisting of HOTS components. The questions that have been collected are then analyzed based on the level of critical thinking according to the description of the revised version of Bloom's taxonomy.

To find out the implementation of HOTS in French learning related to the objectives, indicators, steps of HOTS implementation in learning process and evaluation, the researchers used teachers' lesson plans as secondary data. To get deeper and broader information, the researchers also conducted in-depth interviews with French teachers with question guidelines concerning the item writing for final exam, teacher mastery/knowledge of characteristics of HOTS items and also critical-based learning.

Data analysis in qualitative research is carried out during data collection and after completing data collection within a certain period. The method of data analysis in this study uses data reduction, data display and drawing conclusion/verification.

\section{Results and Discussion}

\subsection{Results}

In this study, 8 assesment documents consisting of 4 final exams packages (odd semester) and also 4 packages of even semester were used. They were taken from 5 high schools or vocational high school in Lampung. The total number of items in the 8 question packages is 348 consisting of 173 items for odd semester and 175 questions for even semester. The majority of items are in the form of multiple choice objective tests with 5 answer choices. There are only 15 questions in the form of a limited form of essay test.

In accordance with the selected grade level, the subject of the questions tested refers to the syllabus of French language and literature subjects for class $\mathrm{X}$ which discusses greeting, saying goodbye and thanking (saluer, prendre congé et remercier), introducing oneself (se présenter) , talking about identity (donner l'identité), stating hour, day, date, month, year (situer dans le temps), objects and public buildings (les endroits publics), describing things or peoples (décrire une personne ou une chose), giving instructions (instructions, panneaux), and exemplifying song lyrics (parole d'une chanson). The questions are then analyzed based on the criteria contained in the thinking process stage of the revised Bloom's taxonomy. 
Taxonomy means the classification or grouping of objects according to certain characteristics. In the field of education, the taxonomy aimed at classifying learning objectives is classified into three domains, namely 1) cognitive domain, relating to learning goals that emphasize thinking skills, 2) affective domains to feelings, emotions, value systems, and heart attitudes. , and 3) psychomotor domain which relates to motor skills. Taxonomy for these instructional purposes is numerous, generally using the name of the creator.

The cognitive domain is one of the aspects that is the target of learning and gets more attention than the other two domains. The cognitive domain is a domain that includes mental (brain) activities. Sudjana states that the cognitive domain is the target of learning outcomes related to memory about knowledge, skills, and intellectual abilities [5]. Bloom's taxonomy in the cognitive domain is the most recognized basic framework for categorizing educational, test and curriculum objectives in the world [6].

The thinking framework in Bloom's taxonomy is divided into 6 levels arranged from the simplest to the most complex, namely knowledge, comprehension, application, analysis, synthesis and evaluation. This taxonomy was then revised by Anderson and Krathwol by changing the categories in Bloom's taxonomy which initially used nouns to verbes so that this cognitive domain was more lively and applicable for educators and learning practices so that it was hoped that it could help educators in processing and formulating learning objectives and assessment strategies. Bloom's Taxonomy has been perfected to remember $(\mathrm{C} 1)$, understand (C2), apply (C3), analyze (C4), evaluate (C5) and create (C6) [5],[4],[7],[8].

Broadly speaking, remembering $(\mathrm{C} 1)$ means remembering or recalling information that has been learned (in memory), understanding (C2) means using memory to describe, explain, or give examples related to something and applying (C3) is using knowledge, rules, principles and things that have been understood to apply to different situations that have never been experienced before. Furthermore, analyzing (C4) means identifying and understanding parts of the material or the whole material, evaluating (C5), namely connecting elements to form a new whole, and creating (C6) means developing new problem solving strategies. After analyzing the 348 questions with reference to the description for each level in Bloom's taxonomy which has been perfected, the results are as shown in the following table:

Table 2. Item Analysis Based on Revised Bloom Taxonomy

\begin{tabular}{|c|c|c|c|c|c|c|}
\hline \multirow{2}{*}{$\begin{array}{c}\text { Thinking Process Level } \\
\text { (Revised Bloom Taxonomy) }\end{array}$} & \multicolumn{5}{|c|}{ School } & \multirow{2}{*}{$\begin{array}{c}\text { Number of } \\
\text { question }\end{array}$} \\
\hline & I & II & III & IV & $\mathbf{V}$ & \\
\hline Remembering & 21 & 14 & 72 & 7 & 14 & 128 \\
\hline Understanding & 65 & 57 & 14 & 23 & 26 & 185 \\
\hline Applying & 12 & 4 & 4 & 6 & 0 & 26 \\
\hline Analyzing & 2 & 3 & 0 & 4 & 0 & 9 \\
\hline Evaluating & 0 & 0 & 0 & 0 & 0 & 0 \\
\hline Creating & 0 & 0 & 0 & 0 & 0 & 0 \\
\hline Total & 100 & 78 & 80 & 40 & 40 & 348 \\
\hline
\end{tabular}

The data in the table shows that the level of thinking that is demanded on the exam items is mostly at the understanding level (C2). No test items is in level of evaluating (C5) and creating (C6). The highest percentage of cognitive level is: remembering (36.78\%), understanding $(53.16 \%)$, applying $(7.47 \%)$, analyzing $(2.58 \%)$, and evaluating and creating respectively $0 \%$. The total results for each cognitive level from the French learning outcome test questions for the five schools are presented as follows: 


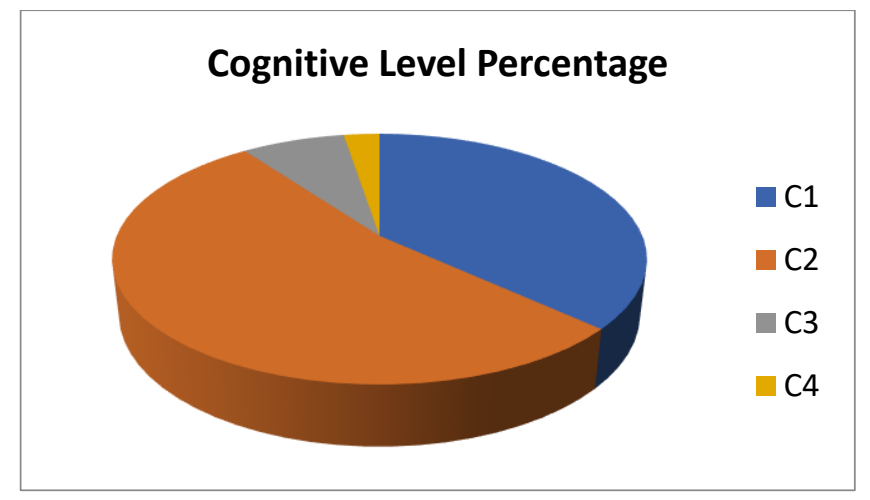

Fig. 1. Cognitive Level Percentage of French Items

The HOTS questions are not synonymous with difficult questions. The difficulty level of the questions is different from the higher order thinking skills. The HOTS problem emphasizes the thinking skills of students who are needed to find the correct answer to the question which is not only remembering, understanding and applying a concept but also being able to connect and compare existing elements /facts so as to be able to create new ideas.

They have several characteristics, namely 1) measuring higher-order thinking skills, 2) divergent, 3) using multiple representation, 4) based on contextual problems and 5) using various types of questions [9].

The results of HOTS characteristics analyses are as follows :

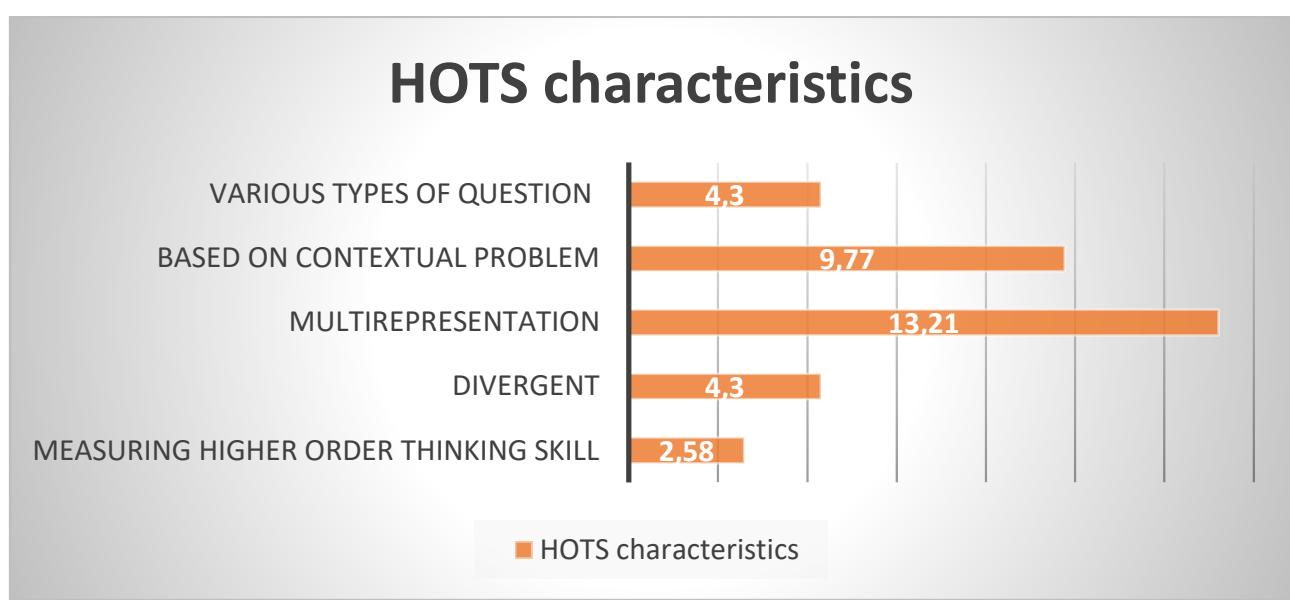

Fig. 2. HOTS characteristics on each item

The chart indicates that the percentage of French language exam questions having HOTS characteristics is still in very small quantity. The largest percentage is dominated by the form of multi-representation questions.

Apparently, the teachers misunderstood the notion of multi-representation. The existence of pictures, numbers, icons does not guarantee that the question is considered as HOTS. Problems with multiple representations is HOTS if to solve the problem, students must refer to pictures, graphs to get the information implied in them, not expressly through the visual or mathematical form in it. 


\subsection{Discussion}

\section{HOTS Implementation in French Evaluation.}

Composition of Cognitive Levels on Class X French Final Exam. This section will discuss one by one the cognitive levels contained in items.

1. Remembering (C1)

Remembering is the lowest cognitive process based on Bloom's revised taxonomy. The meaning of remembering in this case is recalling cognition/ knowledge that is already in memory or recalling facts, concepts and procedures. Although they cannot be used as the main standard, some Operational Verbs (KKO) can be used as references to find out what cognitive processes are involved at this level. These verbs include remembering, registering, repeating and imitating. The percentage of $36.78 \%$ puts this level of thinking in the second most of the total number of questions. The following is example of item that use the ability to remember $(\mathrm{C} 1)$ :

\section{(1) Data No: $\mathrm{I} / \mathrm{A} / 1$}

\begin{tabular}{|c|c|}
\hline \multicolumn{2}{|c|}{ Comment ..... - vous? } \\
\hline a. vais & d. allons \\
\hline b. vase & e. allez \\
\hline
\end{tabular}

Answer key: e

Explanation:

To answer the questions above, students must remember the conjugation of the verb aller for the subject 'vous'. It is an irregular verb so remembering is a thought process that is needed in this case.

2. Understanding (C2)

Understanding is the ability to make descriptions, explain ideas/concepts, or provide examples of something. The operational verbs are commonly used include explaining, receiving, reporting, differentiating etc. The items that demand the ability to think at the level of understanding are the types of questions that are mostly found in data sources, amounting to more than half of the total $(53.16 \%)$ as shown in the following examples:

(2) Data No .: II/E/5

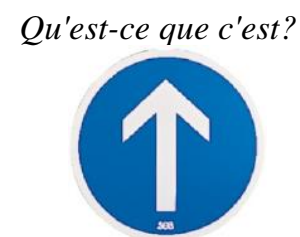
a. Continuer tout droit
d. Le rond-point
b. Tourner à gauche
e. Arrêter
c. Tourner à droit
Answer key: a
Explanation:

To answer this question, students must recall general knowledge, namely the meaning of the traffic sign, then connect it with the correct answer choice by understanding the meaning of the word/phrase in the answer choice.

3. Applying (C3) 
Applying means returning what is understood in a different situation or using information on a different domain. Applying is not necessarily able to solve the problem (problem solving) because it still tends to repeat processes that have been done (routinely). Applying can also mean using certain factual, conceptual and procedural knowledge on other concepts in the same subject or other subjects. Operational verbs that are used include using, demonstrating, illustrating, operating, proving, implementing. The following are examples of items that belong to the $\mathrm{C} 3$ level thinking process:

(3) Data No. I/D/40

Uraikanlah dengan tepat konjugasi bentuk présent untuk kata kerja frapper pada setiap subjeknya (je, tu, il/elle, nous, vous, ils/elles)

Answer key : je frappe, tu frappes, il/elle frappe, nous frapons, vous frappez, ils/elles frappent

Explanation:

French verbs are classified into 3 major groups, namely verbs that end in -er, -ir and $-r e$. Each group of verbs has a certain pattern of formation. Students must be able to apply the concept of regular - er verb conjugation by writing the conjugation of verb frapper for each subject pronoun in French.

4. Analyzing (C4)

Analyzing is the ability to decipher something into smaller parts so that a deeper meaning can be obtained. At this level, the ability to organize and connect between parts is needed so that a more comprehensive meaning is obtained or to evaluate it to find advantages or disadvantages so that new ideas are obtained.

(4) Data No. II/A/1

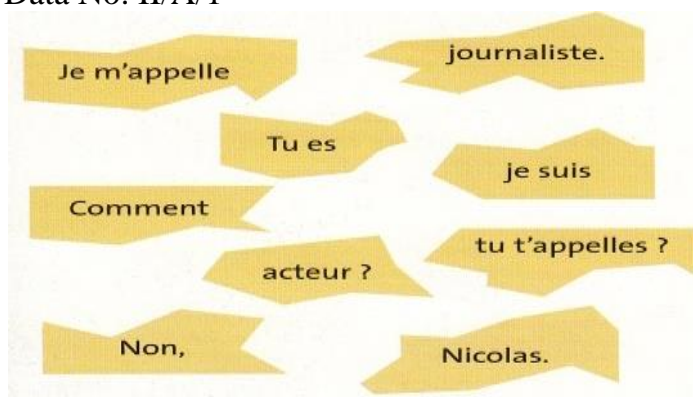

Quelle est la profession de Nicolas?
a. commédien
d. chanteur
b. actrice
e. Journaliste
c. acteur

Answer key : e

Explanation

To answer the above questions, first the students have to be able to understand the vocabulary contained in the sentence fragments then organize/structure the sentence pieces into complete sentences. After that students must be able to combine the sentences that have been formed so that they become acceptable conversations and after that, the answers to these questions will be obtained from the information obtained from the meaning of the dialogue. 


\section{HOTS Characteristics in Items.}

Since the 2013 curriculum came into effect, it is highly recommended for teachers to integrate HOTS in the learning process and especially in the preparation of class assessment questions and school exams. HOTS application in learning in schools is very important in order to increase the level of students' thinking or cognitive abilities. HOTS trains students to have the ability to think critically, creatively, to argue, to make decisions and to solve problems. The habit of high-order thinking will form strong student competencies so that it is very useful for dealing with problems in real life in the increasingly complex future.

Higher order thinking skills include the ability to solve problems (problem solving), critical thinking skills, creative thinking, reasoning skills, and decision making skills. The creative and critical problem solving in HOTS consists of: a) the ability to solve unfamiliar problems, b) the ability to evaluate the strategies used to solve problems from different points of view, and c) find new solving models that are different from the previous way.

1. Measuring Higher Thinking Skill

Analysis of the thinking skills required to work on each item has been carried out. The results of the analysis show that the percentage of questions that require a higher level of thinking is relatively low, namely only $2.58 \%$. Apart from this, the characteristics of the HOTS assessment instrument can be seen from other aspects.

2. Divergent

The HOTS assessment instrument must be divergent, meaning that it allows students to give different answers according to the thought process and point of view used. Divergent thinking is also called creative thinking. Creative thinking is thinking to provide various possible correct answers or ways to a problem based on the information provided with an emphasis on the variety of numbers and suitability. Guilford stated that there are five characteristics of creative thinking abilities, namely fluency, flexibility, originality, elaboration and redefinition.

The form of questions from data sources totaling 348,313 of the total are in the form of multiple choice. Multiple choice questions have many types. The types of multiple choice questions contained in the final tests are dominated by the multiple choice of completing with five choices. This type limits students to think divergent because they do not allow students to give different answers.

3. Using multiple representation

HOTS assessment instruments generally do not present all information in an explicit manner, but force students to dig up implied information themselves. To foster students' critical thinking in selecting and sorting information, HOTS assessment instruments should use various representations including verbal (in the form of sentences), visual (images, charts, graphs, tables, including videos), symbolic (symbols, icons, initials, cues), and mathematical (numbers, formulas, equations). The results of the analysis of 348 items show that some of items present several pictures in the questions besides sentences such as the following example:

(5) Data No : I/B/5 


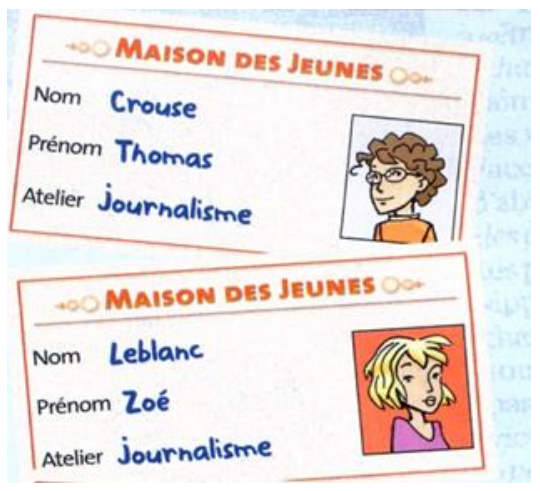

Selon cette image, quelles sont leur profession?
a. Nous sommes journalistes
b. Elles sont journalistes
c. Elle est journaliste
d. Ils sont journalists
e. Il est journaliste

To answer this question, students do not only read the sentence questions but must also look at the picture. Students must look at the picture and the written text to find out the subject pronouns for two people (male and female).

4. Based on Contextual Problems

The five characteristics of contextual assessment (REACT) are relating (related to real life experiences), experiencing (extracting, discovering and creating), applying (applying knowledge to solve real problems), communicating (communicating the conclusions of the model to the conclusion of the problem context), transferring (transforming the concept of knowledge in a new situation or context).

HOTS questions are an assessment based on real situations in everyday life, where students are expected to be able to apply learning concepts to solve problems. Contextual in the context of foreign language learning, including how students are able to overcome communication problems when faced with oral and written communication situations encountered in real life such as filling out biodata forms, asking questions about personal data when registering for courses, shopping (asking and bargaining prices), make appointments and so on. Some of the questions in the data source meet these criteria as in the following example:

(6) Data No. : II / B / 5

Akmal: C'est samedi. Tu es libre ce soir?

Haifa: Oui

Akmal: Je veux regarder le film. What is veux regarder also?

Haifa: C'est intéressant. On va aller ensemble pour regarder le film.

a. au restaurant

d. au musée

b. à la gare

e. à la boucherie 


\section{c. au cinéma}

There is a conversation between friends that discuss invitations to do activities to spend spare time. The context of this conversation is common in everyday life. To answer these questions, students must understand the overall content of the conversation so that they can determine the place in question. The number of questions that use contextual problems in the research data source is still very limited. There are still many questions that do not provide a stimulus or are not based on the context of communication in real life. These questions focus a lot on questions that measure the understanding of grammar usage and the meaning/ translation of the meaning of certain words or expressions.

5. Using various types of question

The various forms of questions in a test set need to be considered by the teacher so that the assessment carried out guarantees the principle of objectivity. Alternative question forms that can be used to write HOTS items include multiple choice and descriptions.

As mentioned above, the total number of items used as a data source is 348 (it should be 350 because two questions are repetitions). The composition of the types of questions consisted of 333 multiple choice objective tests with 5 answer choices, 5 questions in the form of a complementary test and 10 questions in the form of short descriptions. Based on interviews with French teachers, the use of tests which are almost entirely in the form of simple multiple choice is based on the reasons for the ease of correction and the limited time for the exam, namely 60 - 90 minutes for 40 50 questions per exam package.

The choice of question form depends on the objectives to be achieved from a lesson. Each form has advantages and disadvantages of each. Some of the characteristics of HOTS questions include being divergent, which means that it allows students to give different answers according to the thought process and point of view used. Thus the description questions are more appropriate to measure the higher thinking skills of students. In contrast to objective tests such as multiple choice, this type of question is more difficult to use to measure this ability. This is confirmed by Sudijono who says that objective tests are generally less able to measure or reveal high or deep thinking processes. This weakness is mainly due to the fact that in order to provide answers on objective tests, which are generally short answers, testees are not required to think deeply [10].

Another important thing obtained from this study in terms of items writing/composing was that there were still packages written in Indonesian.. Although the time is still relatively short in studying French which has an impact on the limited mastery of vocabulary and grammar, writing test questions should still use French. The teachers should be able to arrange questions in French by paying attention on the level of vocabulary and grammar mastery of the students. The use of French in exam questions includes efforts to develop students' thinking skills because to be able to answer questions students are required to understand French vocabulary and grammar from the written or text that is read.

\section{HOTS Implementation in learning process.}

Assessment in education is not an independent process. It is closely related to the objectives and learning activities undertaken. Providing assessment with questions that require 
higher thinking skills cannot be separated from goal setting and implementation of learning which also integrates thinking skills at the same level.

The implementation of the 2013 Curriculum according to Permendikbud No.22/2016 concerning standards process using 3 (three) learning models are expected to shape scientific, social behavior and develop curiosity. The application of several learning models such as project-based learning, problem-based learning, discovery / inquiry learning help teachers to be able to apply HOTS which are characterized inn learning by, namely 1) focusing on questions , 2) analyzing / assessing arguments and data, 3) defining concepts, 4) determining conclusions, 5) using logical analysis, 6) processing and applying information, and 7) using information to solve problems. Apart from these three models, other learning models can also be used such as cooperative learning which has several methods such as Jigsaw, Numbered Head Together (NHT), Make a Match, Think Pair-Shape (TPS) and so on.

To find out the objectives and learning activities carried out by teachers in schools whose examination instruments were finally used as a source of data in this study, the researcher used the lesson plan as a reference source to determine the implementation of HOTS in the French learning process in school. In addition to lesson plans, researchers also use in-depth interview techniques to dig up more information regarding this matter.

Of all the schools used, four out of five teachers have complete lesson plans for class X, while one teacher does not own but uses lesson plans made by French teachers from other schools. Some of the lesson plans that have been collected use the old form and the rest use the new form of lesson plans in accordance with Permendikbud No. 14 of 2019 concerning the simplification of lesson plan. The results of the analysis of the description of learning objectives as well as the steps listed in the learning plan prove that most of them have been formulated with attention to learning models that prioritize a scientific approach to train students' critical thinking by using, for example, project-based learning models and discovery learning. Based on the analysis of the learning steps contained in the lesson plans, it is known that some French teachers have implemented HOTS learning models/ methods, namely the scientific approach with the cooperative learning method and discovery/inquiry learning that directs students. to independently or in groups know, understand, apply and evaluate.

The ability to set goals and arrange steps and learning activities / methods in the lesson plan to develop students' ability in higher-order thinking is not evenly distributed among French teachers from the five schools. In addition, the results of interviews with teachers revealed conditions in the field that most teachers did not fully understand the meaning of higher thinking skills, learning steps that emphasized the scientific approach and compiled questions with HOTS characteristics. The discrepancy between the data contained in the lesson plans and the results of the interviews with the teachers shows that the lesson plans are still merely to fulfill administrative completeness.

Higher order thinking is not innate. This ability is the result of a habit that is continuously carried out. It is important for teachers to understand teaching methods that develop level thinking and apply them in teaching practice so that students become familiar with them. Morever, Nguyen et al. stresses that explicit instruction of HOTS in the learning and assessment could positively influence students' learning in terms of the learning process, performance in assessment, creativity, and motivation to learn [11].

The French syllabus for class $X$ consists of eight basic competencies which based on interviews are usually divided into 5 basic competencies in odd semesters and 3 in even semesters. This depends on the active week that is in each semester. The syllabus is a learning plan for a group of subjects that includes competency standards, basic competencies, indicators, materials and so on. It is also the translation of competency standards and basic competencies 
into subject matter/learning, learning activities, and competency achievement indicators for assessment. In addition, it is useful as a basic resource guide in developing further learning, starting from making lesson plans, managing learning activities, and developing an assesment system.

Looking at the description of the syllabus in French class $\mathrm{X}$ which consists of 8 basic competencies, it is known that the operational verbs for existing knowledge competencies are dominated by the verb 'exemplify'.. Based on the division of thinking level abilities according to the revised Bloom's taxonomy, this operational verbs are included in the $\mathrm{C} 2$ level (understand) and are found in basic competencies (KD) 3.1, 3.2, 3.3, 3.4, and 3.8. Likewise, the operational verb 'describe' which is used in KD 3.6 include in the C2 level. Whereas for KD 3.5 and 3.7 the operational verb used is to 'differentiate' which includes in the C4 level (analyzing) means category of higher order thinking (HOTS).

According to the Process Standards in the Regulation of the Minister of National Education (Permendiknas) Number 41 of 2007, competency achievement indicators are behaviors that can be measured and / or observed to show the achievement of certain basic competencies which are the reference for subject assessment. Competency attainment indicators are formulated using measurable operational verbs, which include knowledge, attitudes and skills. Not a few teachers directly reduce the formulation of basic competencies to become indicators of competency achievement. This is what ultimately affects the teacher in compiling the questions. If the indicators used have not shown the ability to think highly, it will be difficult to get questions, especially on the final exam which is included in the HOTS category.

\section{Teachers' Understanding Level of HOTS.}

To obtain secondary data related to teachers' understanding of HOTS and its implementation in objectives, learning process and evaluation of French, researchers used indepth interview technique. It is done because there are only five respondents. In addition, with the absence of time restrictions, the information obtained is more than using a questionnaire. In connection with the current situation which is still during the pandemic of Covid-19, interviews were conducted through direct communication via WhatsApp (WA) one by one.

In this study, researchers used semi-structured interviews. This means that researchers do not use interview guidelines that have been arranged systematically and completely for data collection. The interview guide is used only in the form of an outline of the problems to be carried out.

Before conducting the interview, the researcher first made an interview guide that was designed with the aim that the implementation of the focused interview and the topics discussed did not go too far from the research objectives. But in implementation, researchers can ask additional questions in order to find problems and deeper answers. Guidelines or outlines of questions regarding the preparation of final semester exam questions, teacher knowledge of HOTS and implementation or integration of HOTS in class X French learning.

Regarding the writing items of the test, the results of the interviews show that time constraints and ease of correcting are reasons for most teachers to choose the multiple choice form ( 5 choices). The time allocated to work on 40 - 45 questions ranges from 60 - 90 minutes. Furthermore, only around $50 \%$ of the questions tested on the final examination of class $\mathrm{X}$ were composed by the teachers themself. The purpose of composing by yourself in this case is that the teacher designs, compiles questions and answer choices without imitating questions on the internet or other sources. For the rest, the teacher uses sample questions available from internet sources or handbooks (méthode de français) such as LeMag ', Adomania and others. 
The suitability of the questions with the material being taught and the difficulty level of the questions are what the teacher takes into account in compiling the items. The level of thinking required in the problem is not of concern. In addition, the questions given on the exam are generally questions of the same type given in practice during the learning process or questions in daily tests are only changed for less significant parts such as names, numbers etc. The number of new questions tested is less than $25 \%$.

The next question is the teacher's level of understanding about cognitive levels based on Bloom's taxonomy and the revised version, the definition of HOTS, the classification of LOTS and HOTS level, learning characteristics and instruments with HOTS characteristics. Almost all teachers stated that they did not understand this. Some know the term HOTS from training/seminars in which it was mentioned. There is only one teacher who has attended special HOTS training. The teacher's lack of understanding of HOTS has an impact on the preparation/writing of questions for exam that do not consider higher-order thinking skills on them.

Most teachers have heard of several learning models that can be used to develop students' cognitive levels such as discovery/inquiry learning, project-based learning, problem-based learning, cooperative learning, but they do not understand how to perform or how to structure learning using these methods. . In practice, learning is still carried out traditionally or teachercentered in which teachers are the main source of information.

To organize HOTS-type learning as well as to prepare HOTS assessement requires of course the teacher's mastery of HOTS itself. Without that, it is likely impossible if students can also develop their high order thinking skill. In fact, teacher's knowledge about thinking skills and pedagogy are the most important factors influencing the implementing thinking skills [12].

\section{Conclusion and Suggestion}

\subsection{Conclusion}

This study aims to identify the cognitive level of items contained in the French final exam questions for class X. In addition to the cognitive level, this study also analyzes whether these items contain HOTS characteristics. The results of the analysis show that the French class $\mathrm{X}$ questions taken from 8 package of questions covering five schools in Lampung have already contained questions that measure students' higher order thinking skills. However, this type of problem is still in a very low percentage. The results of the analysis show that the composition of the questions on the exam already contains questions with HOTS characteristics consecutively as follows : remembering/C1 (36.78\%), understanding/C2 (53.16\%), applying/C3 (7.47\%), analyzing/C4 (2.58\%). The level of $\mathrm{C} 2$ or understanding dominate the questions. The analyses of HOTS characteristics such as measuring the higher thinking level, divergent, multiple representations, based on contextual problem and various types of questions in items writing shows that majority of the items do not meet the criteria. The use of questions or items which demand the mastery of grammar is still significant. The domination of multiple choice objective test are poorly treated which do not allow the students think creative. Based on the interview with the teachers, it was revealed that most teachers are not familiar with higher order thinking skill. This ignorance resulted in a lack of attention to integrating HOTS in the French language learning and evaluation process. On the other hand, the description of basic competencies in French syllabus that they use as reference in determining objectifs dan learning process does not relfect either the higher thinking order. 


\subsection{Suggestion}

Teaching is an activity that requires careful preparation. starting from formulating indicators, setting goals, compiling learning steps and also preparing assessment/ evaluation instruments. The writing of items in the evaluation is not independent of other learning aspects. It can not be held without support of the others. It all comes down to achieve the educational goals. Integrating HOTS in process and evaluation activities also requires extra effort and intention from the teacher because teaching is not only transferring knowledge but building characters. Ability of high level thinking is not innate but results of habits. Therefore, teachers must apply this habit in every aspect of learning. Difficulty is not same as higher order thinking skill. HOTS is not intended for high achiever students, but can be given at any level of education. It is the teacher's duty to adjust according to the level of mastery of the students.

Acknowledgments. We would like to thank French teachers, members of the professional organization APFI antenne Lampung, for their contribution and cooperation in this research.

\section{References}

[1] Panicker, C.M.V, Yunus, M \& Embi, M.A. Teacher Trainees' Role in Implementing Higher Order Thinking Skills in the ESL Classroom. IJARIIE. 2019. Vol.5, Issue 2.

[2] Yen, T. S \& Halili, S. H. Effective Teaching of Higher-Order Thinking Skill (HOTS) in Education. The Online Journal of Distance Education and E-Learning (TOJDEL). 2015. 41 - 47.

[3] Arikunto, S. Dasar-Dasar Evaluasi Pendidikan. Jakarta: Bumi Aksara. 2009.

[4] Dinni, H. N. HOTS (Higher Order Thinking Skill) dan Kaitannya dengan Kemampuan Literasi Matematika. Prisma I (Prisma, Prosiding, Seminar Nasional Matematika). 2018.

[5] Ahmad, I. F \& Sukiman. Analisis Higher Order Thinking Skill (HOTS) pada soal ujian akhir siswa kelas 6 KMI dalam kelompok mata pelajaran Dirasah Islamiyah di Pondok Modern Tazakka Batang. Jurnal Pendidikan Agama Islam. 2019. Vol 16. No.2.

[6] Singh, R.K.A, Singh, C.K.S, Tunku, Mostafa, N.A \& Singh, T.S.M. A Review of Research on The Use of Higher Order Thinking Skills to Teach Writing. International Journal of English Linguistics. 2018. 8 (1).

[7] Gunawan, I \& Palupi, A.R. Taksonomi Bloom-Revisi Ranah Kognitif: Kerangka Landasan untuk Pembelajaran, Pengajaran dan Penilaian. Jurnal Premiere Educandum. 2012. Vol.2, No.02.

[8] Putra, T. K \& Abdullah, D. F. Higher-Order Thinking Skill (HOTs) Questions in English National in Indonesia. The Journal of Educational Development (JED). 2019. 7 (3).

[9] Setiawati. Buku Penilaian Berorientasi Higher Order Thinking Skills. Program Pengembangan Keprofesian Berkelanjutan (PKB) melalaui Peningkatan Kompetensi Pembelajaran Berbasis Zonasi: Direktorat Jenderal Guru dan Tenaga Kependidikan Kementrian Pendidikan dan Kebudayaan. [2019].

[10] Sudijono, A. Pengantar Evaluasi Pendidikan. Jakarta: PT. Rajagrafindo Persada. 2015.

[11] Nguyen T.M.T \& Nguyen, T.T.L. Influence of explicit higher order thinking skills construction on students learning of linguistics. Elsevier. 2017. 26, 113-127

[12] $\mathrm{Li} \mathrm{Li}$. Integrating thinking skills in foreign language learning. What can we learn from teacher's perspectives? Elsevier. 2016. 22, 273-288. 